Filozofska fakulteta, Univerza v Ljubljani

mojca.medvedsek@ff.uni-lj.si

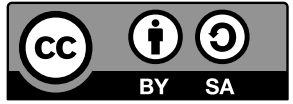

\title{
PORTUGUÊS LÍNGUA NÃO MATERNA: INVESTIGAÇÃO E ENSINO
}

Rosa BIZARRO, Maria Alfredo MOREIRA, Cristina FLORES (2016). Português Língua Não Materna: Investigação e Ensino. Lisboa: LIDEL. ISBN-978-972-757-928-0, 194 strani, $30,20 €$.

V zbirki, ki izhaja s podporo portugalskega Ministrstva za znanost in tehnologijo, Ensino e Aprendizagem do Português para Falantes de Outras Línguas, (Poučevanje in učenje portugalščine za govorce drugih jezikov, ur. Maria José Grosso) je na Portugalskem izšlo obsežno delo več avtoric, zbor člankov in raziskav, namenjen poučevanju portugalščine kot nematernega jezika ${ }^{1} \mathrm{z}$ naslovom Português Língua Não Materna: Investigação e Ensino (Portugalščina kot nematerni jezik: raziskave in poučevanje). Urednice te izdaje ter obenem avtorice obsežnega uvoda, vodilne strokovnjakinje na področju izobraževanja profesorjev portugalščine kot drugega, nematernega jezika in raziskovalke na tem področju, so delo razdelile v dva sklopa: prvi del je sestavljen iz petih poglavij, posvečenih teoretičnim dognanjem tako s področja poučevanja PNMJ kot nekaterih vidikov dvojezičnosti (bilingvizma), drugega pa sestavlja sedem poglavij, ki obravnavajo dvojezično izobraževanje in izobraževanje učiteljev.

V uvodu avtorice pojasnijo kontekst nastanka publikacije: Portugalska je v zadnjem desetletju postala dežela, $v$ kateri zatočišče iščejo številni migranti, kar pred izziv postavlja mnoge učitelje, ki se v vedno večjem številu soočajo z učenci, katerih materni jezik ni portugalščina. $V$ delu so tako zbrane izkušnje profesorjev v visokošolskih ustanovah, raziskovalcev in udeležencev različnih evropskih projektov, ki so svoja dognanja delili na istoimenskem kolokviju, ki ga je organizirala Univerza v Portu.

$\mathrm{V}$ teoretičnem delu publikacije večina avtorjev obravnava kritična področja s področja poučevanja PNMJ. Tako na primer Maria Helena Araújo Carreira, z Univerze Paris 8 - Vincennes, Saint Denis, v poglavju z naslovom "Algumas Especificidades da Língua Portuguesa do Ponto de Vista do Ensino do Português Língua Segunda e Língua estrangeira: Problematização" (Nekatere specifike portugalskega jezika s perspektive

1 V nadaljevanju PNMJ. (op.avt.) 
poučevanja portugalščine kot drugega/tujega jezika, str. 25-33), na podlagi dolgoletne prakse predstavi problem različnih sociolingvističnih in kulturnih profilov učencev ter poudarja: »da morajo biti lingvistične posebnosti portugalskega jezika nujno prilagojene sociolingvističnemu profilu učencev« (str. 32).

Cristina Flores, v poglavju "Português Língua Não Materna: Discutindo Conceitos de uma Perspetiva Linguística"(Portugalščina kot nematerni jezik: razprava o konceptih v lingvistični perspektivi), na straneh 35 do 46 prinaša razpravo o konceptu portugalščine kot »jeziku dediščine« (português língua herança), ki mu raziskovalci posvečajo pozornost šele od leta 2012. Avtorica poudarja prednost učencev, ki jih tradicionalno obravnavajo kot učence portugalščine drugega/tujega jezika in opozarja na nujnost, da se v državah, ki so povezane s portugalsko zgodovino migracij (in v katerih se jezik še vedno govori, vendar ima dandanes pogosto drugačen administrativni ali socialni status), to pojmovanje v prihodnosti dokončno uveljavi in izkoristi svojo specifiko v procesu poučevanja.

V perspektivi poučevanja PNMJ se Helena Ançã, v članku "Saberes Vulgares de Africanos sobre a Língua Portuguesa: um Contributo para o Português Língua Não Materna” („Ljudsko poznavanje portugalskega jezika Afričanov: prispevek k poučevanju PNMJ“, str. 81-91), izhajajoč iz teorije Folk Linguistics, ukvarja s sociolingvističnimi predstavami afriških govorcev, ki bivajo na Portugalskem, o portugalščini in lastnih, maternih jezikih, pri čemer poudarja pomembnost določenih prepričanj posameznikov v procesu učenja PNMJ, zlasti kar zadeva metalingvistični diskurz, s katerim so soočeni učeči.

Drugi del publikacije prinaša razprave o izobraževanju učiteljev, povezane z naraščajočo lingvistično in kulturno raznolikostjo učencev ter nujnostjo kontrastivnih pristopov z drugimi jeziki, ki jih učenci obvladajo ter o pomenu razvijanja multikulturnih praks, ki povečujejo zavest o večjezičnosti.

Avtorice Joana Duarte, Maria Alfredo Moreira in Cristina Flores, v članku "Bilinguismo e Educação: um Novo Currículo para a Formação de Professores” (Dvojezičnost in izobraževanje: nov kurikul za izobraževanje učiteljev (str. 111-128), skušajo predstaviti evropski projekt EUCIM-TE, ki poučevanje jezikov povezuje z ostalimi vsebinami v osnovnošolskih in srednješolskih kurikulih učencev, zlasti z usvajanjem veščin akademskega jezika, ki naj ne bi bilo več zgolj stvar predmeta jezika (maternega, drugega, tujega) temveč tudi vseh drugih predmetov. Avtorice skušajo prikazati možen model prilagoditve tega evropskega kurikula razmeram na Portugalskem.

V 8. poglavju avtorji Dulce Pereira, Pedro Martins in Vanessa Antunes, v prispevku z naslovom "Educação Bilingue e Aprendizagem do Português em Contexto Multilingue" (Dvojezično izobraževanje in učenje portugalščine v večjezičnem kontekstu, str. 121-143) predstavijo izkušnjo dvojezičnega poučevanja portugalščine/kapverdščine in projekt Dvojezična izmena (Turma Bilingue) v osnovnih šolah prve triade na Kapverdskih otokih. V razpravi izpostavijo lingvistične in medkulturne prednosti tako za otroke, katerih materin jezik je kapverdščina, kot za tiste, ki kot materni jezik uporabljajo portugalščino, zlasti kar zadeva večjo sposobnost abstrakcije in krepitev lingvistične zavesti. 
Eden zadnjih prispevkov "A Formação de Professores de Língua Não Materna na Faculdade de Letras da Universidade do Porto: Questões Interculturais e Ensino Inclusivo do Português Língua Segunda" (Izobraževanje učiteljev portugalščine kot nematernega jezika na Filozofski fakulteti v Portu: vprašanja medkulturnosti in inkluzivnega poučevanja portugalščine kot drugega jezika) avtoric Rose Bizarro in Fátime Braga, precej skrbno predstavi pojem inkluzivnosti pri medkulturnih temah pri poučevanju portugalščine in se nasloni na izkušnje izobraževanja bodočih učiteljev PNMJ Filozofske fakultete v Portu. Članek obravnava nekatere zakonske ovire pri tovrstnem izobraževanju učiteljev, ki je lahko zaradi le-teh nepopolno in neučinkovito in razgrne problem pojma inkluzivnega šolanja in medkulturnega izobraževanja, ki temelji zgolj na evropsko napisanih ali predstavljenih besedilih, ki so navadno osnova za poučevanje portugalščine kot drugega/tujega jezika.

Zbirka prispevkov, raziskav in člankov je dragoceno branje in pomembna referenca za vse učitelje portugalščine kot drugega/tujega jezika, saj prinaša različna videnja in izkušnje, ki se prepletajo, ponavljajo in dopolnjujejo, zlasti pa kažejo na kompleksnost problema, ki ga predstavlja poučevanje PNMJ v današnjem svetu. 